\author{
Journal of Information System and \\ Technology Management (JISTM) \\ Journal Website: http://jistm.com/ \\ eISSN: 0128-1666
}

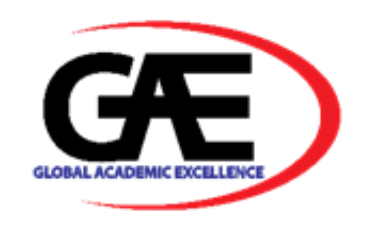

\title{
A CASE STUDY ON THE APPLICATION OF WEB-BASED BLENDED LEARNING
}

\author{
Nurien Hidayu Muhamad Rusly ${ }^{1}$, Azureen Abd Aziz ${ }^{2}$, Suhaila Ngadiron ${ }^{3}$
}

1 Centre of Liberal Arts and Languages, INTI International University (IIU), Malaysia

Email: nurien.rusly@newinti.edu.my

2 Centre of Liberal Arts and Languages, INTI International University (IIU), Malaysia

Email: azureen.abdaziz@newinti.edu.my

3 Centre of Liberal Arts and Languages, INTI International University (IIU), Malaysia

Email: Suhaila.ngadiron@ @ewinti.edu.my

\section{Article Info: \\ Article history: \\ Received date: 09.01.2020 \\ Revised date: 19.01 .2020 \\ Accepted date: 14.06 .2020 \\ Published date: 15.06.2020 \\ To cite this document: \\ Rusly, N. H. M., Abd Aziz, A., \& Ngadiron, S. (2020). A Case Study on The Application of Web-Based Blended Learning. Journal of Information System and Technology Management, 5 (17), 20-27.}

DOI: $10.35631 /$ JISTM.517003.

\begin{abstract}
:
This empirical study focuses on private university students' perceptions regarding the advantages and limitations of web-based blended learning using a learning website. The focus is on the use of a learning website as an additional learning method combines with the traditional face to face learning instructions. This new method of learning is known as Blended Learning. It is transforming learning and teaching in higher education institutions. The sample consist of 40 randomly picked university students from various programs. Two questions raised: (1) What are students' perceptions of the advantages of web-based learning? (2) What are students' perceptions regarding the limitations of web-based learning? The results indicate clear advantages of this new experience in broadening students' views on different methods of learning. Furthermore, this study highlighted that the learning web serves as helpful simulations in which enable students to experience the real learning experience and enable students to interact with each other virtually. The component on advantages gathered students' feedback on how the learning website provides an environment for more effective learning strategies. However, several research findings showed some gaps and limitations that need to be handled wisely. This paper is to discover the roles and challenges of web-based learning on students' learning.
\end{abstract}

\section{Keywords:}

Web-Based Learning, Blended Learning, Advantages, Limitations 


\section{Introduction}

\section{Background}

Web-based learning signifies to the type of learning that uses technology and the Internet as an instructional delivery tool to carry out various learning activities. It can take the form of either a pure online learning in which the curriculum and learning are implemented online without face-to-face meeting between the instructor and the students; fully online learning, or a mixture in which the instructor meets the students half of the time online and half of the time in the classroom, depending on the needs and requirement of the curriculum; blended learning. Webbased learning can be integrated into a curriculum that turns into a full-blown course or as a supplement to traditional courses.

In Malaysia, over the past few years, the implementation and application of technology in teaching and learning activities have fascinated most of the practitioners in the Higher Education Institutions (HEI). Online learning has become one of the fastest growing trends in educational uses of technology. It involves the concern that fully online or blended learning has been growing in demand and popularity in HEI and has become an extensive teaching sensation. The widespread execution of technology in teaching and learning process can prove that online-blended learning can overcome various limitations related to the traditional face toface instruction. Advances in technology have changed the way that many professional educators regard course delivery (Llyod-Smith, 2010). For many researchers, it is almost certain that blended learning will be the new traditional model for course delivery in higher education (Norberg, Dziuban, \& Moskal, 2011).

In the last ten years, HEIs have allocated great resources to support the development and implementation of online learning. This is due to the fact that online learning is one of the fastest growing trends in educational uses of technology (Means et.al, 2013). Therefore, it is essentially important to support the implementation of technology through online learning. An analysis of usage and satisfaction studies from perspective of students as the ultimate client of learning management system (Al-rahmi et.al, 2015). However, students' satisfaction towards the application of web-based learning should be evaluated using various approach; it is to address learners' personal attitudes with respect to any learning management system. The selected private university in Malaysia has provided its students a web-based learning management system environment powered by a learning website since 2014 .

\section{Literature Review}

\section{Blended Learning}

Blended learning is a term progressively used to designate the method e-learning is being combined with traditional classroom methods and independent study to create a new mixture which contribute to the development of a hybrid teaching methodology. It signifies a much better alteration in elementary technique than simply adding computers to classrooms. It denotes, in many cases, a fundamental change in the way teachers and students approach the learning experience. It has already produced the flipped classroom - that has quickly become a separate approach of its own. 
Blended learning could be defined using the following diagram:

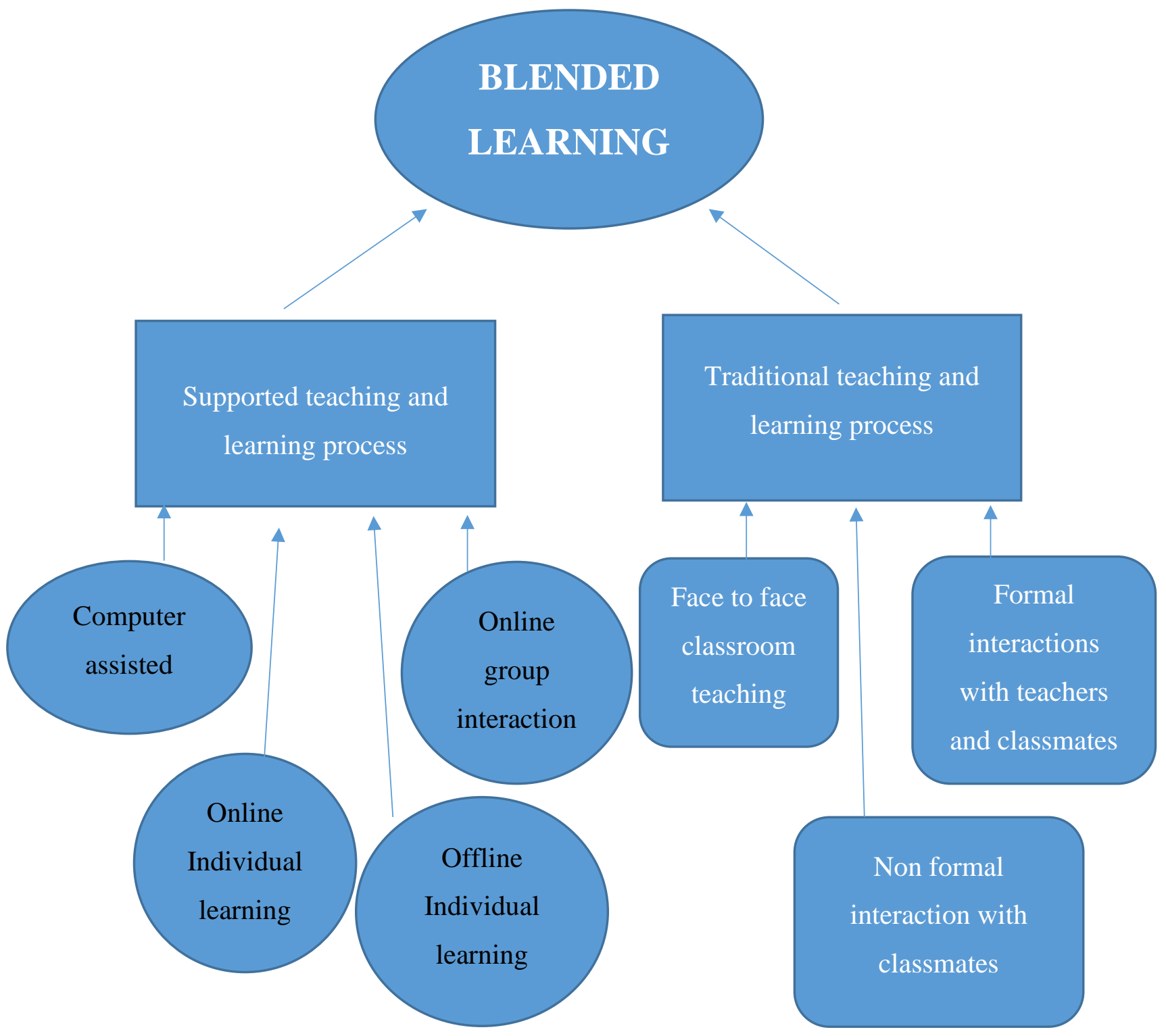

The nature of blended learning involves teaching and learning process that combines both online and face to face learning. Blended learning incorporates direct and indirect instructions, collaborative teaching, computer-assisted learning and web-based learning. Webster's Online Dictionary defines blending as mixing elements and combining the elements into one. In relation to the nature of blending elements in a course, proper planning and mixing should be applied to ensure effective mixing. Therefore, the structure of the course must be carefully evaluated to determine which instructional objectives can best be met in an online environment and which are better suited to a face to face. In order for true blending to occur, the structure of the course must be carefully evaluated to determine which instructional objectives can best be met in an online environment and which are better suited to a traditional classroom environment.

As blended learning integrates adaptive technology, monitoring progress analysis and includes the suggested action plan by customizing instruction for students makes educators become more focused. Next step planning contributes to tome-efficient and successful in improving skills for students. Educators will accept blended learning once they are included in the Copyright $\odot$ GLOBAL ACADEMIC EXCELLENCE (M) SDN BHD - All rights reserved 
planning and decision-making processes, educators will be able to recognize the positive outcomes of blended learning. In addition, educators can acquire essential skills or help to develop skills to achieve what they are asked for. It is the very reason why strong leadership is key in creating consensus, building infrastructure and then executing the web-based blended learning model. Using the model is the best way to tailor lessons and use mastery-based learning to improve students' overall performance by incorporating face-to-face and web-based learning strategies.

\section{Methodology}

The study adopted quantitative method on an experimental group of 40 students as respondents. The respondents were degree students from sections that have completed a full semester of a blended course. The students have experienced web-based learning using a learning website on a course. The aim is to gather information on the advantages and limitations of Web-based blended learning using the learning website. The study took place in one of the private universities in Malaysia. The respondents were selected using random sampling. The sample was taken on the basis of their judgement of their typicality of the particular characteristics being sought (Cohen et.al, 2007). For the study, questionnaires were used to collect data from the respondents. The respondents were able to reflect on their experiences on web-based learning to answer questions provided in the survey. The survey design was used because of it suitability in reviewing advantages and limitations of web-based learning specifically the use of the learning website in teaching and learning. The respondents were gathered in a class and they were given sufficient time to complete the survey. After the respondents completed the survey, the researcher collected the survey, data gathered was later analyzed and tabulated.

\section{Findings and Discussion}

The survey was conducted on 40 students as respondents, the students were those who have completed a full semester of a blended course. The researchers obtained data from the survey based on 2 open-ended questions. The two open-ended questions are (1) What are the advantages of web-based blended learning? (2) What are the limitations faced related to webbased blended learning?

The table below shows the strengths and weaknesses of web-based blended learning method that can be concluded by the researchers. The previous researchers have reported that there are still the needs to the face to face contact in the online learning. Stodel, Thompson and MacDonald (2006) found that there are three areas of presence identified in what the learners are missing in the online learning: social presence, cognitive presence and teacher presence.

Table 1.0: The Strengths of Web-Based Blended Learning

\begin{tabular}{|c|c|}
\hline & Strengths \\
\hline \multirow{6}{*}{ Communications } & 1. Easy to communicate with lecturers \\
\hline & $\begin{array}{l}\text { 2. Clear instructions related to homework / tasks could be } \\
\text { shared via website }\end{array}$ \\
\hline & 3. Students can be easily connected to the lecturers \\
\hline & $\begin{array}{l}\text { 4. Communication with classmates and the lecturer is easier } \\
\text { via learning website }\end{array}$ \\
\hline & 5. Communication is possible and easy via discussion forum \\
\hline & $\begin{array}{l}\text { 6. Easy and convenience to understand instructions and } \\
\text { lectures plan }\end{array}$ \\
\hline
\end{tabular}




\begin{tabular}{|c|c|}
\hline \multirow{4}{*}{ Sharing updates } & $\begin{array}{l}\text { 1. Latest information could be shared via announcement } \\
\text { board }\end{array}$ \\
\hline & 2. Latest information could be shared very fast \\
\hline & $\begin{array}{l}\text { 3. Latest information about courses could be received via } \\
\text { website }\end{array}$ \\
\hline & $\begin{array}{l}\text { 4. It is easy and convenience - it will increase learning } \\
\text { proficiency }\end{array}$ \\
\hline \multirow{3}{*}{ Practicality } & 1. Easy to be used \\
\hline & 2. Convenience and everything is just a click away \\
\hline & $\begin{array}{l}\text { 3. The learning website could be used for online discussions } \\
\text { - method of communication among classmates }\end{array}$ \\
\hline \multirow{2}{*}{ Active discussions } & $\begin{array}{l}\text { 1. Thoughts and opinions could be shared via discussion } \\
\text { board }\end{array}$ \\
\hline & 2. Notes and short videos are always available in the website \\
\hline \multirow{9}{*}{ Effective content sharing } & 1. Notes sharing \\
\hline & $\begin{array}{l}\text { 2. Course content allows students to know topic(s) to be } \\
\text { discussed in advance }\end{array}$ \\
\hline & $\begin{array}{l}\text { 3. Course syllabus could be seen clearly in the learning } \\
\text { website }\end{array}$ \\
\hline & $\begin{array}{l}\text { 4. Learning resources and associated activities are } \\
\text { convenient }\end{array}$ \\
\hline & $\begin{array}{l}\text { 5. Resources for registered courses are available in the } \\
\text { learning website }\end{array}$ \\
\hline & 6. Supporting notes are available in the website \\
\hline & $\begin{array}{l}\text { 7. Very easy to get notes as files could be downloaded } \\
\text { straight away from the learning website }\end{array}$ \\
\hline & 8. Resources are available to support lecture \\
\hline & 9. Very convenience to study at home or everywhere \\
\hline \multirow[b]{2}{*}{ On the go/limitless } & 1. No limitation in terms of time \\
\hline & $\begin{array}{l}\text { 2. The web-based learning application is available from } \\
\text { play store and app store }\end{array}$ \\
\hline
\end{tabular}

Table 2.0: The Weaknesses of Web-Based Blended Learning

\begin{tabular}{|c|c|}
\hline & Limitations \\
\hline \multirow[b]{3}{*}{ Internet connectivity } & $\begin{array}{l}\text { 1. The learning website cannot be accessed with unstable } \\
\text { internet connection }\end{array}$ \\
\hline & 2. Some laggings due to high traffic at certain time \\
\hline & $\begin{array}{l}\text { 3. The learning website is not available without internet } \\
\text { connection }\end{array}$ \\
\hline & $\begin{array}{l}\text { 1. Lack of knowledge to use some of the available features } \\
\text { of the website - blog }\end{array}$ \\
\hline & $\begin{array}{l}\text { 2. Some features/functions are unnecessary - it is not being } \\
\text { used }\end{array}$ \\
\hline & $\begin{array}{l}\text { 3. Some features are not connected directly to students' } \\
\text { smartphones }\end{array}$ \\
\hline & 4. Some features are a bit complicated for new users \\
\hline
\end{tabular}




\begin{tabular}{|c|c|}
\hline \multirow{3}{*}{ Website's features } & $\begin{array}{l}\text { 5. Students are not familiar with some of the features in the } \\
\text { website }\end{array}$ \\
\hline & 6. Some documents cannot be downloaded from the website \\
\hline & 7. No calendar update/reminder available in the website \\
\hline Login & $\begin{array}{l}\text { 1. It is hard to remember specific information/domain } \\
\text { needed to login }\end{array}$ \\
\hline
\end{tabular}

As the web-based blended learning has offered both strengths and weaknesses, it is great to use details from both categories to improve on the delivery of teaching and learning method. Webbased blended learning applies the use of controlled technology in the physical classroom. The technology available creates a variety of resources and contributes to enhance experiential learning. Combination of multiple delivery media designed to complement each other and promote learning and application learned behavior (Singh, 2003). Although online learning offers a modern set of tools which add value to conventional learning methods, consideration should be given to the limitations of online learning in order to improve the learning environment. From the findings shared above, the Strengths of Web-Based Blended Learning could be classified into three main advantages Enriched Communication and Support Interaction, Offers Flexibility and Efficiency and Mobility and limitless. Further explanation of the advantages is discussed below.

\section{Enriched Communication and Support Interaction}

Blended education, through software connects people, activities and events. It is a key tool for the global creation and exchange of cultural understanding. However, communication between learners and instructor as well as learners and learners, may create online communities and active learning practices where products of information, ideas and experience are shared and appreciated.

\section{Offers Flexibility and Efficiency}

The learning website offers flexibility and efficiency in teaching and learning activities. Teaching and learning session could be conducted via interactive video or teleconference students could actively take part in the online session. Notes, study materials, research and additional resources can be easily navigated through the web.

\section{Mobility and Limitless}

With the growing and active use of mobile and wireless technology, learning process could be at anytime and anywhere. The integration of delivery mechanisms, instructional approaches, technologies and learning circumstances must be developed to promote learning that is individualized, but collaborative and interactive. The learning process should be prompt and geared towards a common need that is still part of a lifelong learning journey. It is therefore possible for such technologies to make learning more easily accessible and to foster a rich, interactive learning experience.

\section{Conclusion}

Teaching and learning are an evolutionary process, it never ends. It has evolved from a total instructor/classroom dependent stage to an online environment. The emerging of computer and other technologies had made teaching and learning activity a very dynamic process. This study is conducted to gather learners' perceptions on strengths and weaknesses on the implementation of web-based blended learning approach. The paper has outlined the precise definition of web-based blending and some of the strengths of this approach. 
In the context of designing web-based blended learning framework and model, the challenge faced by educators and learners when technology-focus is in place is to maintain the flexibility and imagination to adapt the tool to new uses as they arise (Chew, Jones \& Turner, no date). Again, according to Chew et.al (no date), today, blended learning researchers seem to have an emphasis toward practices without a clear understanding of or underpinned educational theories.

Hence, the need to explore educational theory and its relationship with technology is essential. And as well, the power and potential of the technological and the skills of the teacher should be blended together to offer totally great learning experience to learners at all levels. A wellblended learning approach is expected to be able to cater for the diverse needs of most learners. The results indicate clear strengths of this new experience in broadening students' views on different methods of learning. The study highlighted that the learning web serves as helpful simulations in which enable students to experience the real learning experience and enable students to interact with each other virtually. The component on advantages gathered students' feedback on how the learning website provides an environment for more effective learning strategies. However, several research findings showed some gaps and limitations that need to be handled wisely.

\section{Reference}

Alammary, A, Sheard, J \& Carbone, A (2014). Blended learning in higher education: Three different design approaches. Australasian Journal of Education Technology 30(4), pp 440-454.

Al-rahmi, W.M, Othman, M.S, Mi Yusuf, L (2015). The effectiveness of using E-learning in Malaysian Higher Education: A case study Universiti Teknologi Malaysia. Mediterranean Journal of Social Sciences MCSER Publishing, Rome-Italy 6(5), pp 625-637.

Brooke, E (2017). Four keys to success using blended learning implementation models. Retrieved May 29, 2010 from http://net.educause.edu/ir/library/pdf/ERB0407.pdf [Accessed 20 July 2019]

Chew, E., Jones, N., Turner, D. (no date). Critical Review of the Blended Learning Models based on Maslow 's and Vygotsky 's Educational Theory. University of Glamorgan, United Kingdom.

Dziuban, C., Hartman, J., and Moskal, P. (2004) Blended learning. Edu cause Center for Applied Research, Research Bulletin, (2004)7. Available at: http://net.educause.edu/ir/library/pdf/ERB0407.pdf [Accessed 20 July 2019]

HeeYoung Kim, J, (2008). Types of Blended Instruction: Different Approaches to Different Mixes.Armstrong Atlantic State University. Available at: https://members.aect.org/pdf/Proceedings/proceedings13/2013i/13_21.pdf [Accessed 31 December 2019].

Jeffrey, L. M., Milne, J., Suddaby, G., \& Higgins, A. (2014). Blended learning: How teachers balance the blend of online and classroom components. Journal of Information Technology Education: Research, 13, 121-140. Available at: www.jite. org/documents/Vol13/JITEv13ResearchP121-140Jeffrey0460. pdf

Kassim, Z, Ahmad, A.R (2010). E-pembelajaran:Evolusi internet dalam pembelajaran sepanjang hayat. Proceedings of Regional Conference on Knowledge Integration in ICT, pp 209-218. Available at: file://C:/Users/nurien.rusly/Desktop/paper\%20kuching/E- 
PEMBELAJARAN_EVOLUSI_INTERNET_DALAM_PE.pdf [Accessed 20 July 2019].

Kementerian Pengajian Tinggi Malaysia. 2007. Pelan Strategik Pengajian Tinggi Negara Melangkah Tahun 2020. Putrajaya: Kementerian Pengajian Tinggi.

Kudrik, Y, Lahn, L.C. \& Mørch, A.I. (2009). Technology-Enhanced Workplace Learning: Blended Learning in Insurance Company. Paper presented at 17th International Conference on Computers in Education. Hong Kong: Asia-Pacific Society for Computers in Education.

Llyod-Smith, L. (2010). Exploring the Advantages of Blended Instruction at Community Colleges and Technical Schools. MERLOT Journal of Online Learning and Teaching, [online] 6(2), pp.508-515. Available at: file://C:/Users/nurien.rusly/Desktop/paper\%20hatyai/lloyd-smith_0610.pdf [Accessed 20 July 2019].

Lyod-Smith, L, (2010). Exploring the advantages of blended instruction at community colleges and technical schools. MERLOT Journal of Online Learning and Teaching 6(2), pp 508-515.

Malaysia, Rancangan Malaysia ke-11 (RMK11). Available at: https://www.intanbk.intan.my/iportal/index.php/ms/rmk11

Sands, P. (2002). Inside outside, upside downside: Strategies for connecting online and faceto-face instruction in hybrid courses. Teaching with Technology Today, 8(6). Available at: from http://www.uwsa.edu/ttt/articles/sands2.htm [Accessed: 1 January 2019].

Singh, H. (2003). Building Effective Blended Learning Program, Educational Technology, 43(6), pp 51-54. 